nurse-cells; the resting egg arises from a modified group of four cells, which absorbs numerous other four-celled groups. The author confirms Weismann's statements that the origin of resting eggs is not connected with any influence of the male, that these eggs do not enter the brood pouch, but if not fertilised degenerate in the ovary, that the carapace of Daphnia changes into an ephippium only if the ovary is forming resting eggs, and that these eggs invariably give rise to females.

(6) The Donaciinæ, a sub-family of the Chrysomelidæ (leaf-beetles), are of special interest on account of certain peculiar features in the habitat and mode of life of the larvæ, which are fully described and illustrated in Dr. Böving's memoir, which also contains an exhaustive account of the larval anatomy. The author concludes that the features hitherto utilised to differentiate the larvæ of Hæmonia and Donacia are unserviceable; it has, in fact, not been possible to find real generic distinctions between the larvæ, although the adults present well-marked differences. Conversely, though the adults of Donacia and Plateumaris have been found to exhibit only small differences, from which it might have been expected that the larvæ would be difficult to distinguish, it is shown that the larvæ of Plateumaris, here described for the first time, are dissimilar from those of all other Donaciinæ. The larvæ gnaw the roots of certain aquatic plants (Potamogeton, Sparganum, Carex, \&c.), and while doing so arrange the head and prothorax so that the latter forms with the plant a water-tight compartment in which the head can work undisturbed by, and the food be kept from admixture with, water and dirt. The mandibles of the larva have a cutting, and not a crushing, edge; they cannot be used for grinding, and, in fact, serve only to make an entry into the plant tissue, the sap of which then exudes and is received by the laciniæ of the maxillæ and passed backwards into the gut. The larvæ seem to feed exclusively on the sap; an examination of the gut contents, which consist of a homogeneous yellow fluid, shows that cell-fragments are not present. The external features of the head, the mouth parts, the muscles, and the mechanism of feeding are considered in great detail.

Aquatic insects have adopted various devices for obtaining a sufficient supply of air; the larvæ of the Donaciinæ have chosen a very remarkable one, namely, to tap the reservoirs of air in the intercellular spaces of the submerged parts of plants. At the posterior end of the abdomen is the "abdominal organ," which the author shows to be a bifore spiracle. The terminal hook of this organ is plunged into the vegetable tissue, air passes from the latter into the organ, and apparently through thin membranes into an atrium, which leads into the main trachea. The spiracular slit in the abdominal organ serves for expiration.

The making of the cocoon is described at length. The outer envelope is formed by a secretion of the whole body, and is lined with a substance produced in four large csophageal glands; the larva gnaws one or two holes through the bottom of the finished cocoon so as to make connection with the air spaces of the root to which it is attached; air is thus secured for the pupal stage. The author gives a list of the food plants of the different species of larvæ of this family found in Denmark, and accounts of the gnawings, the sizes of the larvæ at different periods, the length of larval life, hibernation, the flying period of the adults, the eggs, and the postembryonic development. The memoir forms a substantial addition to our knowledge of the anatomy, biology, and development of these interesting larvæ.

J. H. A.

\section{PHYSICAL ANTHROPOLOGY OF} AUSTRALASIAN RACES.

IN the Proceedings of the Royal Society of Edinburgh for the present session (1910-Ir) appears a series of four papers devoted to the physical anthropology of the races of Australasia. The papers are by three authors, two of them human anatomists, Prof. R. J. Berry and Dr. A. W. W. Robertson, the third a mathematician, Mr. K. Stuart Cross. The authors seek to fix the position of the Tasmanian and Australian natives amongst present and past races of manNO. 2 I69, VOL. 86$]$ kind by applying biometrical methods to certain measurements of the skull.

The most valuable paper of the series is that by Dr. Robertson, where he gives the data obtained from measurements of 100 Australian crania. By applying Prof. Karl Pearson's test for purity of race, Dr. Robertson finds the native Australians are "pure" when the measurements of the width of the cranium is considered, but "impure" when the lengths are investigated. It will be seen that Dr. Robertson's results are somewhat equivocal, and may be quoted in support of either the unity or duality of the Australian race. Similar methods applied to the Tasmanian race show a much higher degree of homogeneity or purity. The difference in purity between the Australian and Tasmanian races may be explained by the fact that one is spread over a large continent, while the other is confined to a small island.

An attempt is also made by the authors to fix the position of the much-discussed Tasmanian race in the scale of human evolution. The result will somewhat surprise those who have sought to establish racial relationships on an analysis and comparison of mere anatomical characters, for by the methods here employed the Dschagga negro comes out as the advance guard of the human race, well in front of the European, while the native Tasmanian gains a good place, being sandwiched between two ancient Europeans-the man of Brünn and the Cro-magnon race.

From an anatomical point of view the results are surprising, for it would be hard to find greater cranial contrasts than those between the Tasmanian and Cro-magnon on one hand, and the Tasmanian and Brünn on the other. There can be no doubt, however, as to the high value of the new data with which these papers supply anthropologists.

\section{THE PRODUCTION AND IDENTIFICATION OF ARTIFICIAL GEMS.}

I PROPOSE to limit the term " artificial" to such productions as possess the same chemical composition and physical constants as the natural stones, differing from them only in minute details consequent upon their being produced in the laboratory instead of being dug out of the earth, all other makeshifts being properly described as "imitations."

The scientific examination and identification of gems is a matter of the greatest interest, but it would take far too much time to discuss it in detail; and it is quite unnecessary to do so, because it has already been brought before the society most exhaustively by our chairman, Dr. Miers. ${ }^{2}$ I propose, therefore, merely to remind you of the main points.

In order to bring this matter up to date, however, I must refer briefly to one or two particulars in which advance has been made since the time of these lectures.

The most important properties of a precious stone are those depending upon its refractive powers. Until recently, the accurate determination of the refractive index of a stone was a matter involving the use of complicated and expensive instruments, and a matter for the skilled mineralogist rather than the practical jeweller. It is true that at the time Dr. Miers published his lectures there existed an instrument known as the reflectometer, but the determination of the refractive index with this was a matter of some difficulty even in skilled hands, and its value for commercial purposes was very small. Since that time, however, thanks to the ingenuity of Dr. Herbert Smith, this instrument has been improved out of all recognition, and in its place we have the Herbert Smith refractometer (Fig. I), by means of which anyone of normal common sense can determine the refractive index of a stone in a few seconds without even removing it from its setting, and which, with a little practice, will also enable one to determine with similar ease the amount and kind of double refraction and the degree of dispersion.

Taking the properties of precious stones as a whole, the great point about them is the remarkable combination of qualities; it is not so much that they have optical

1 Ahstract of a paper read before the Royal Society of Arts on April 26, igri, by Noel Heaton.

2 Cantor Lectures on Precious Stones, A pril, x896. 